\title{
Pengaruh Financial Leverage Terhadap Harga Saham Syariah dengan Inflasi sebagai Variabel Moderating
}

\author{
Jenal Alamsah dan Ahmad Eko Adi
}

Sekolah Tinggi Ilmu Ekonomi Dwimulya

Email: Jeans_1468@yahoo.com, ahmad.ekoadi@gmail.com

\begin{tabular}{l}
$\frac{1}{\text { Artikel }}$ \\
\hline info \\
Artikel history: \\
Diterima 03 Mei 2021 \\
Diterima dalam bentuk \\
revisi 12 Mei 2021 \\
Diterima dalam bentuk \\
revisi 18 Mei 2021
\end{tabular}

Keyword:

asset financial leverage; inflation; islamic stock proces.

\section{Kata Kunci:}

financial leverage, inflasi, harga saham syariah

\begin{abstract}
The purpose of this study is to determine the Influence of Financial Leverage on Sharia Stock Prices with Inflation as a Moderating Variable in companies that are members of the Jakarta Islamic Index of the Indonesia Stock Exchange for the 2016-2020 Period. The method used is quantitative, with research instruments of corporate financial statements. The results of the study, partially Financial Leverage has a significant influence on Sharia Stock Prices where the significance obtained is $0.000<0.05$. Meanwhile, the results of the Moderating Regression Analysis test, which is to test the influence of inflation as a moderating variable, show the results in the regression equation for the interaction variable of Financial Leverage and Inflation of -8877.24 , which means that if there is an increase in inflation, it will reduce the influence of Financial Leverage on Islamic stock prices. Based on the significance value of the moderating interaction variable of 0.007 $<0.05$, this means that inflation is the moderating variable.
\end{abstract}

\begin{abstract}
Abstrak
Tujuan penelitian ini yaitu untuk mengetahui pengaruh Financial Leverage terhadap Harga Saham Syariah dengan Inflasi Sebagai Variabel Moderating pada perusahaan yang tergabung dalam Jakarta Islamic Index Bursa Efek Indonesia Periode 2016-2020. Metode yang digunakan adalah kuantitatif, dengan instrument penelitian laporan keuangan perusahaan. Hasil penelitian, secara parsial Financial Leverage berpengaruh Signifikan terhadap Harga Saham Syariah dimana diperoleh signifikansi sebesar $0.000<0.05$. Sedangkan hasil uji Moderating Regression Analysis yaitu untuk menguji pengaruh Inflasi sebagai variable moderating, diperoleh hasil dalam persamaan regresi variable interaksi Finanacial Leverage dengan Inflasi sebesar - 8877.24 yang berarti jika terjadi kenaikan inflasi maka akan menurunkan pengaruh Finanacial Leverage terhadap harga saham syariah. Berdasarkan nilai signifikansi variable interaksi moderating sebesar $0.007<$ 0.05 hal ini berarti Inflasi sebagai variable moderating.
\end{abstract}

Coresponden author: Jenal Alamsah Email: Jeans_1468@yahoo.com artikel dengan akses terbuka dibawah lisensi

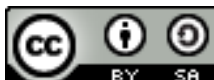

\section{Pendahuluan}

Berbagai kebijakan pemerintah dalam menumbuhkan iklim investasi di Indoneisa telah dilakukan, diantaranya mengubah ekonomi berbasis sumber daya alam ke ekonomi berbasis nilai tambah yaitu industri manufaktur dan jasa. Demikian juga dengan kebijakan perdagangan 
sebagai upaya pemerintah dalam mendorong peningkatan produk ekspor dengan melibatkan diri sebagai bagian dari Global Value Chain, sehingga mampu memotong prosedur dalam menekan biaya dan waktu serta efisiensi logistik serta diplomasi ekonomi dan peningkatan pasar.

Kebijakan pemerintah ini akan semakin meningkatkan gairah investasi di dalam negeri, meskipun kebijakan pemerintah tersebut bukanlah satu-satunya jalan keluar dalam mengatasi kesulitan para pelaku industri. Kebutuhan modal untuk membiayai produksi dan operasional sering kali menjadi kendala tersendiri bagi perusahaan, terlebih ketika modal sendiri sudah tak mampu membiayai operasi perusahaan, sehingga manajemen sering kali harus memutuskan jenis pendanaan atas operasi yang harus dijalankannya dengan tetap mempertimbangkan kelangsungan usahanya.

Persaingan usaha semakin meningkat seiring dengan berjalannya waktu, sehingga diperlukan strategi agar selain dapat bertahan, perusahaan harus mampu bersaing. Persaingan akan membuat perusahaan melakukan strategi pengembangan yang berkonsekuensi pada kebutuhan dana, sementara perusahaan memiliki keterbatasan sumber daya sehingga seringkali kebutuhan dana menjadi kendala, disisi lain akses perbankan untuk perolehan dana merupakan masalah yang banyak dihadapi perusahaan. Penambahan dana dari para pendiri atau pinjaman dari perbankan hanyalah solusi sementara, karena juga memiliki keterbatasan seiring dengan berkembangnya perusahaan.

Perolehan dana baru dilakukan perusahaan dengan cara menjual saham perusahaan kepada publik. Namun demikian, harga saham akan dipengaruhi oleh faktor-faktor fundamental perusahaan selain faktor lain seperti tingkat suku bunga, inflasi dan kondisi ekonomi negara. Faktor fundamental perusahaan menjadi perhatian publik, karena para investor harus memastikan bahwa investasinya dapat memberikan keuntungan. Salah satu faktor fundamental perusahaan adalah Financial Leverage yang menggambarkan penggunaan dana dalam rangka pembiayaan yang diukur dengan rasio jumlah hutang dengan aktiva yang disebut debt ratio. Jika perusahaan memiliki debt yang tinggi maka perusahaan juga memiliki beban atas pengembalian berupa beban bunga. Oleh karena itu Financial Leverage menjadi bahan perhatian karena pada umumnya para investor menghindari risiko

Penelitian mengenai pengaruh Financial Leverage terhadap harga saham dilakukan oleh (Racmat dan Mella Putri, 2017) pada perusahaan pada sub sektor perkebunan dengan hasil bahwa Financial Leverage berpengaruh negatif terhadap harga saham. Hal ini menunjukkan bahwa semakin tinggi Financial Leverage akan menurunkan harga saham. Sedangkan penelitian yang dilakukan oleh Saparudin dan (Maisaroh \& Yando, 2020) dengan judul Pengaruh Profitabilitas dan Leverage terhadap harga saham perusahaan manufaktur diperoleh hasil bahwa Leverage berpengaruh tidak signifikan terhadap harga saham. Perbedaan ini dimungkinkan karena perbedaan subjek penelitian dimana pada penelitian Saparudin ini menggunakan seluruh perusahaan manufaktur sehingga dapat menggambarkan bahwa perusahaan manufaktur memiliki kemampuan berbeda dalam mengatasi persoalan leverage.

Penelitian lain pada saham syariah dilakukan oleh (Akbar \& Afiezan, 2018) dengan judul Determinasi Harga Saham Syariah melalui Analisis Terhadap Faktor Fundamental dan Makro Ekonomi, penelitian ini dilakukan pada saham syariah yang terdaftar di Jakarta Islamic Index. Salah satu variable fundamental yang digunakan adalah Debt To Equity Ratio yang merupakan 
rasio Financial Leverage. Hasil penelitiannya menunjukkan bahwa Debt To Equity Ratio berpengaruh signifikan terhadap harga saham syariah.

Pada penelitian ini penulis mengembangkan penelitian pada saham syariah mengingat dalam Islam Investasi dianggap sebagai kegiatan muamalah, sedangkan Indonesia memiliki pemeluk Islam terbesar. Oleh karena hal tersebut perbedaan penelitian penulis adalah menggunakan inflasi sebagai variabel moderat, sehingga pada penelitian ini diharapkan dapat memberikan gambaran lebih jelas bahwa pengaruh Inflasi dapat memperkuat atau memperlemah pengaruh Financial Leverage terhadap harga saham syariah. Dengan demikian, para calon investor selain melihat faktor fundamental, dapat juga memperhatikan tingkat inflasi yang berlangsung sebagai bahan pertimbangan dalam mengambil keputusan investasi.

Saham syariah merupakan surat berharga sebagai tanda bukti kepemilikan aset perusahaan yang dikeluarkan oleh emiten dimana kegiatan usahanya dan cara pengelolaannya tidak bertentangan dengan prinsip syariah. Penyertaan modal dalam bentuk saham yang tergolong syariah dapat dilakukan dengan menggunakan akad musyarakah dan mudharabah. "Akad musyarakah umumnya dilakukan pada saham perusahaan privat, sedangkan akad mudharabah umumnya dilakukan pada saham perusahaan public (Al Arif, 2012).

Harga saham dalam hal ini saham perusahaan publik merupakan harga suatu saham yang terjadi di pasar bursa pada saat tertentu. Harga saham di pasar bursa ditentukan oleh para pelaku pasar dalam hal ini berhubungan dengan kekuatan Supply dan demand saham. Sementara itu Supply dan Demand saham ini dipengaruhi oleh berbagai faktor baik faktor fundamental perusahaan maupun faktor makro. Pada penelitian ini harga saham syariah adalah harga penutupan (closing price) saham syariah pada perdagangan terakhir yang terjadi dalam suatu periode.

Inflasi adalah kondisi saat harga-harga barang/jasa secara umum mengalami kenaikan terus-menerus sehingga dapat menurunkan nilai mata uang di negara setempat (Purnomo \& Hariyani, 2013). Inflasi ringan merupakan tingkat inflasi di bawah $10 \%$ per tahun. Inflasi sedang berkisar antara 10\% sampai dengan 30\%. Sedangkan inflasi tinggi berkisar 20\% sampai dengan $100 \%$ yang akan berdampak pada pertumbuhan ekonomi.

Hyperinflation adalah inflasi yang berada pada angka di atas $100 \%$ per tahun. Tingkat inflasi ini akan memperburuk kondisi ekonomi suatu negara. Hyperinflation dapat dimaknai sebagai inflasi yang tak terkendali dimana harga-harga melonjak secara cepat tetapi kenaikan pendapatan secara umum tidak mengalami peningkatan, sehingga jumlah uang beredar terlalu banyak sementara nilai mata uang menurun drastis. Suatu negara yang mengalami Hyperinflation, nilai mata uang lokalnya akan mengalami pengikisan dari nilai sebenarnya, sehingga mata uang mengalami penurunan daya beli. Sebaliknya dalam kondisi ini, mata uang asing justru mengambil peranan dalam perekonomian lokal, karena nilainya cenderung lebih stabil. Tingkat inflasi yang digunakan dalam penelitian ini merupakan tingkat inflasi rata-rata tahunan yang dipublikasi Bank Indonesia dari tahun 2016-2020.

Kebijakan perusahaan untuk mendapatkan modal pinjaman dari luar memerlukan pemikiran bidang manajemen keuangan, karena dengan menggunakan hutang akan menanggung beban tetap berupa bunga. Financial leverage merupakan penggunaan dana dengan beban tetap dengan harapan atas penggunaan dana tersebut akan memperbesar pendapatan per lembar saham atau mengukur tingkat kepekaan perubahan laba per lembar saham atau EPS terhadap perubahan EBIT (Kamaludin dan Indriani, 2012). 
Financial leverage adalah rasio yang menunjukan proporsi atas penggunaan utang untuk membiayai perusahaan dibandingkan dengan modal perusahaan. Perusahaan yang tidak mempunyai financial leverage berarti menggunakan modal sendiri (Agus Sartono, 2012).

Penggunaan financial leverage yang besar akan membawa dampak positif bila pendapatan yang diterima dari penggunaan dana tersebut lebih besar daripada beban tetapnya. Sebaliknya jika financial Leverage yang besar tapi tidak mampu menghasilkan kelipatan bunga memadai, maka perusahaan akan dihadapkan pada kesulitan membayar kewajiban bahkan akan sampai pada gagal bayar.

Dalam penelitian ini Financial Leverage menggunakan debt to equity ratio yang menggambarkan sampai sejauh mana modal pemilik dapat menutupi utang-utang kepada pihak luar. Semakin kecil rasio ini semakin baik. Rasio ini dicari dengan cara membandingkan antara seluruh utang, termasuk utang lancar dengan seluruh ekuitas. Semakin tinggi rasio ini berarti modal sendiri semakin sedikit dibandingkan dengan hutangnya.

Formula Debt to Equity Ratio adalah sebagai berikut :

$$
\text { DER }=\frac{\text { Total Hutang }}{\text { Total Ekuitas }}
$$

Berdasarkan uraian diatas, penulis selanjutnya menggambarkan model penelitian sebagai berikut :

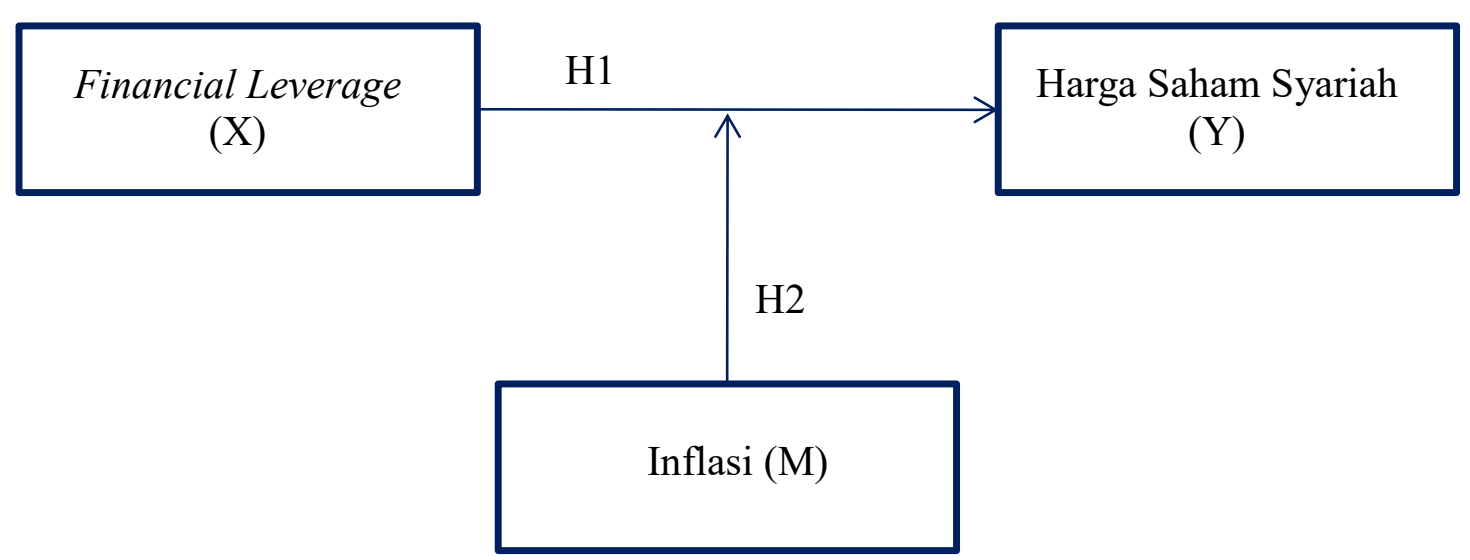

Gambar 1 : Model Penelitian

Berdasarkan uraian pendahuluan dan model penelitian, penulis merumuskan hipotesis penelitian :

H1 = Financial Leverage Berpengaruh Signifikan terhadap Harga Saham Syariah .

H2 = Inflasi Memoderasi Pengaruh Financial Leverage terhadap Harga Saham Syariah.

\section{Metode Penelitian}


Jenis penelitian yang digunakan dalam penelitian ini adalah penelitian kausal yang bertujuan untuk menguji hipotesis tentang pengaruh satu variabel independen terhadap variabel dependen. Sedangkan metode penelitian adalah cara atau jalan yang ditempuh sehubungan dengan penelitian yang dilakukan, yang memiliki langkah-langkah yang sistematis. Metode penelitian dapat diartikan sebagai cara ilmiah untuk mendapatkan data yang valid dengan tujuan dapat ditemukan, dikembangkan, dan dibuktikan, suatu pengetahuan tertentu sehingga dapat digunakan untuk memahami, memecahkan, dan mengantisispasi masalah (Sugiyono, 2014).

Variabel yang digunakan dalam penelitian ini adalah Fiancial Leverage dengan menggunakan Rasio Debt To Equity Ratio (X), Harga Saham Syariah (Y) dan Inflasi sebagai Variable Modetaring (M). Variabel Moderating adalah variabel yang memperkuat atau memperlemah hubungan antara variabel dependen dan independen (Ghozali, 2016). Data inflasi yang digunakan dalam penelitian ini adalah data inflasi yang diperoleh dari website Bank Indonesia (www.bi.go.id) yang diukur dengan satuan persen (\%).

Populasi adalah wilayah generalisasi yang terdiri dari atas obyek/subyek yang mempunyai kualitas dan karakteristik tertentu yang ditetapkan oleh peneliti untuk dipelajari dan kemudian diambil kesimpulannya. Dalam penelitian ini, populasi menggunakan perusahaan yang terdaftar di Jakarta Islamic Index periode 2016-2020. Sedangkan Sample adalah bagian dari jumlah dan karakteristik yang dimiliki oleh populasi tersebut. Populasi yang besar tidak memungkinkan untuk dipelajari secara keseluruhan, Sampel yang digunakan adalah sampel yang diharapkan mewakili dari populasi yang ada (Sugiyono, 2014). Dalam penelitian, penulis menggunakan teknik pengambilan sampel purposive sampling yaitu sampel diambil berdasarkan kriteria tertentu sesuai dengan tujuan penelitian yang dianggap mewakili penelitian. Kriteria pemilihan sampel sebagai berikut :

1. Perusahaan yang listing di Jakarta Islamic Index (JII) secara konsisten selama periode 2016-2020

2. Perusahaan yang listing di Jakarta Islamic Index (JII) konsisten mempublikasikan LK secara lengkap selama periode 2016-2020

Analisis data menggunakan analisis regresi linear berganda dan metode Moderated Regression Analysis (MRA) dengan menggunakan program software Statistical Package for Social Sciences (SPSS). Sebelum dilakukan uji regresi, terlebih dahulu dilakukan uji asumsi klasik karena model regresi linier berganda dapat disebut baik jika terbebas dari asumsiasumsi klasik statistik, yaitu Normalitas, Multikolinieritas, Heteroskedastisitas dan Autokorelasi.

1. Uji Normalitas, bertujuan untuk menguji apakah dalam model variabel dependen dan variabel independen keduanya mempunyai distribusi normal atau tidak. Model regresi yang baik adalah distribusi data normal atau mendekati normal. Uji normalitas dilakukan dengan menggunakan uji Kolmogorov-Smirnov (Ghozali, 2016) dengan kriteria pengambilan keputusan :

a. Apabila nilai Asymp. Sig. $<0,05$, maka Ho diterima dan Ha ditolak atau data residual terdistribusi tidak normal.

b. Apabila nilai Asymp. Sig. > 0,05, maka Ho ditolak dan Ha diterima atau data residual terdistribusi normal. 
2. Uji Multikolinearitas, Uji ini digunakan untuk mengukur tingkat asosiasi (keeratan) hubungan atau pengaruh antar variabel bebas tersebut melalui besaran koefisien korelasi. Pemeriksaan multikolinearitas dilakukan dengan menggunakan VIF (Variance Inflation Factor). Jika nilai VIF > 10 maka terdapat gejala multikolinearitas yang tinggi.

3. Uji Autokorelasi, Uji Autokorelasi adalah untuk melihat apakah terjadi korelasi antara variabel bebas terhadap variabel terikat, jadi tidak boleh ada gejala autokorelasi antara observasi dengan data observasi sebelumnya. Uji Durbin Watson atau DW test digunakan dalam pengujian autokorelasi. Dengan ketentuan:

a. jika $0<\mathrm{d}<\mathrm{dl}$ maka tidak ada autokorelasi positif

b. jika $\mathrm{dl}<\mathrm{d}<\mathrm{du}$ maka tidak ada autokorelasi positif

c. jika $4-\mathrm{dl}<\mathrm{d}<4$ maka tidak ada autokorelasi negatif

d. jika $4-\mathrm{du}<\mathrm{d}<4-\mathrm{dl}$ maka tidak ada autokorelasi negatif

e. jika du $<\mathrm{d}<4-$ du maka tidak ada autokorelasi positif atau negatif.

4. Uji Heteroskedastisitas, digunakan untuk mengetahui apakah ada perbedaan antara variance dari observasi yang satu dengan observasi yang lain. Jika residual mempunyai varians yang sama disebut homoskedastisitas dan jika varians tidak sama disebut heteroskedastisitas. Persamaan regresi yang baik jika tidak terjadi heteroskedastisitas. Salah satu cara untuk mendeteksi ada atau tidaknya heteroskedastisitas adalah dengan melihat grafik scatterplot antara nilai prediksi variabel dependen ZPRED dengan ini residualnya SRESID (Ghozali, 2016).

5. Analisis Regresi Linear Sederhana, dilakukan untuk mengolah dan membahas data yang telah diperoleh dan untuk menguji hipotesis pertama yang diajukan menggunakan persamaan:

$\mathrm{Y}=\alpha+\mathrm{bX} \ldots \ldots(1)$

Dimana :

$\mathrm{Y}=$ Harga Saham Syariah

$\mathrm{X}=$ Financial Leverage

$\alpha=$ Konstanta

$\mathrm{b} \quad=$ Koefisien regresi

6. Moderating Regression Analysis (MRA)

Selain menggunakan analisis regresi sederhana, dalam penelitian ini juga menggunakan metode Moderated Regression Analysis (MRA) untuk menganalisis pengaruh variabel moderator pada hubungan antara variabel independen terhadap variabel dependen. Metode Moderated Regression Analysis (MRA) merupakan suatu model regresi yang menggunakan variabel moderator. Variabel moderating adalah variabel yang akan memperkuat atau memperlemah hubungan antara variabel independen terhadap variabel dependen. (Gozali, 2016:213). Terdapat tiga cara dalam pengujian regresi dengan variabel moderator, yaitu menggunakan uji interaksi, uji nilai selisih mutlak, dan uji residual. Dalam penelitian ini menggunakan metode uji interaksi dengan persamaan, sebagai berikut :

$\mathrm{Y}=\mathrm{a}+\mathrm{bX}+\mathrm{b} 1 \mathrm{M}+\mathrm{b} 2 \mathrm{X} . \mathrm{M}$

Dimana : 


$$
\begin{array}{ll}
\mathrm{Y} & =\text { Harga Saham Syariah } \\
\mathrm{X} & =\text { Financial Leverage } \\
\mathrm{M} & =\text { Inflasi (variable Moderator) } \\
\alpha & =\text { Konstanta } \\
\mathrm{b}, \mathrm{b} 1, \mathrm{~b} 2 & =\text { Koefisien regresi }
\end{array}
$$

Apabila variabel inflasi (M) merupakan variabel moderator, maka nilai signifikansi koefisien b2 harus lebih kecil dari $\alpha$ (sig. $<5 \%$ ), tetapi jika nilai signifikansi lebih besar dari $5 \%$, maka inflasi bukan variabel moderator.

7. Uji Hipotesis, adalah metode pengambilan keputusan berdasarkan data hasil proses analisis. Dalam statistik, sebuah hasil bisa dikatakan signifikan secara statistik jika kejadian tersebut hampir tidak mungkin disebabkan oleh faktor yang kebetulan sesuai dengan batas probabilitas yang sudah ditentukan sebelumya.

Uji t (Parsial), Uji Parsial adalah uji untuk melihat bagaimana pengaruh masing-masing variabel bebas secara sendiri-sendiri terhadap variabel terikat, uji ini dilakukan dengan membandingkan t-hitung dengan t-tabel atau dengan melihat signifikansi pada masingmasing t hitung. Untuk melakukan uji parsial (uji t), terlebih dahulu menentukan $t$ tabel yang diperoleh berdasarkan $\mathrm{df}=\mathrm{n}-\mathrm{k}-1$ dengan probabilitas 5\%. Sedangkan pengambilan keputusan adalah Jika $t$ hitung $<\mathrm{t}$ tabel maka Ho diterima dan Ha ditolak atau pertumbuhan aset berpengaruh tidak terhadap struktur modal dan Jika t hitung > t tabel maka Ho ditolak dan Ha diterima atau pertumbuhan aset berpengaruh signifikan terhadap struktur modal.

\section{Hasil dan Pembahasan}

Sebelum dilakukan uji regresi, terlebih dahulu dilakukan uji Asumsi Klasik sebagai berikut :

Tabel 1.1

Hasil Uji Kolmogorov Smirnov

\begin{tabular}{llr}
\hline & & $\begin{array}{r}\text { Unstandardi } \\
\text { zed Residual }\end{array}$ \\
\hline $\mathbf{N}$ & & 60 \\
Normal Parameters $^{\mathbf{a}}$ & Mean & .0000000 \\
& Std. Deviation & $8.96385750 \mathrm{E}$ \\
Most Extreme & Absolute & 3 \\
Differences & Positive & .121 \\
& Negative & .121 \\
Kolmogorov-Smirnov Z & & -.067 \\
\hline Asymp. Sig. (2-tailed) & & .938 \\
\hline
\end{tabular}

Uji normalitas dengan menggunakan One-Sample Kolmogorov-Smirnov, sehingga dapat dipastikan bahwa data data berdistribusi normal, dimana berdasarkan Tabel 1.1 nilai signifikan sebesar 0,343 hal ini berarti nilai sig > 0,05 dengan demikian dapat disimpulkan bahwa data berdistribusi normal. 
Tabel 1.2

Hasil Uji Multikolonieritas

\begin{tabular}{llrr}
\hline \multirow{2}{*}{ Model } & \multicolumn{2}{c}{ Collinearity Statistics } \\
\cline { 3 - 4 } $\mathbf{1}$ & & Tolerance & VIF \\
X & & \\
M & 0.38 & 6.199 \\
& XM & 0.317 & 3.154 \\
\hline
\end{tabular}

Uji Multikolonieritas diperoleh nilai $\mathrm{VIF}<10$ dengan demikian disimpulkan tidak terjadi multikolinier, karena nilai $\mathrm{VIF}<10$.

Tabel 1.3

Hasil Uji Autokorelasi

\begin{tabular}{lrrr}
\hline R & R Square & $\begin{array}{c}\text { Adjusted R } \\
\text { Square }\end{array}$ & $\begin{array}{l}\text { Durbin- } \\
\text { Watson }\end{array}$ \\
\hline $\mathbf{. 6 7 6}^{\mathbf{a}}$ & $\mathbf{0 . 4 5 7}$ & $\mathbf{0 . 4 2 8}$ & $\mathbf{2 . 0 1 5}$ \\
\hline
\end{tabular}

Uji Autokorelasi diperoleh nilai DW 7.005 sedangkan dari table Durbin Watson dengan signifikansi $5 \%, \mathrm{n}=60$ serta $\mathrm{k}=3$ diperoleh nilai du sebesar 1.6889 dengan demikian $\mathrm{du}<\mathrm{DW}<4$-du atau 1.6889<2.015<2.3111. Dapat disimpulkan bahwa tidak terjadi autokorelasi.

Selanjutnya dilakukan uji regresi persamaan kesatu menggunakan regresi sederhana dengan hasil berikut :

Tabel 1.4

Hasil uji Regresi Sederhana

\begin{tabular}{|c|c|c|c|}
\hline & \multirow[t]{2}{*}{ Model } & \multicolumn{2}{|c|}{ Unstandardized Coefficients } \\
\hline & & $\mathrm{B}$ & Std. Error \\
\hline \multirow[t]{3}{*}{1} & (Constant) & - & 2101.33 \\
\hline & \multicolumn{3}{|c|}{1147.91} \\
\hline & $\mathbf{X}$ & 11935.89 & 2054.14 \\
\hline
\end{tabular}

Berdasarkan Tabel 1.4 dibentuk persamaan regresi berganda sebagai berikut :

\section{$Y=-1147.91+11935.89 X$}

Persamaan regresi tersebut diinterpretasikan bahwa Harga Saham Syariah akan turun 1147.91 jika Financial leverage bernilai konstan. Jika Financial Leverage naik satu satuan maka Harga Saham Syariah akan bertambah sebesar 11935.89

Untuk pengambilan keputusan penerimaan atau penolakan hipotesis dalam uji parsial (Uji t), terlebih dahulu ditentukan $t_{\text {table }}$ dengan taraf signifikansi $5 \% \mathrm{df}=\mathrm{n}-\mathrm{k}$ dimana $\mathrm{df}=60-2$ $=58$ dengan uji dua sisi diperoleh $t_{\text {tabel }}$ sebesar 2.002. Hipotesis Pengujian adalah :

H0 = Financial Leverage Berpengaruh Tidak Signifikan Terhadap Harga Saham Syariah $\mathrm{Ha}=$ Financial Leverage Berpengaruh Signifikan Terhadap Harga Saham Syariah 
Tabel 1.5

Hasil uji t (Parsial)

\begin{tabular}{lrrr}
\hline \multicolumn{1}{c}{ Model } & $\begin{array}{c}\text { Standardized } \\
\text { Coefficients }\end{array}$ & t & Sig. \\
\cline { 2 - 3 } $\mathbf{1}$ (Constant) & Beta & & \\
\hline $\mathbf{X}$ & $\mathbf{0 . 6 0 7}$ & $\mathbf{5 . 8 1 1}$ & $\mathbf{. 0 0 0}$ \\
\hline
\end{tabular}

Berdasarkan table 1.5 Nilai thitung untuk variabel Financial Leverage sebesar 5.811 atau $5.811>2.002$ yang berarti $t_{\text {hitung }}>\mathrm{t}_{\text {tabel }}$. Dengan demikian Ho ditolak dan Ha diterima atau Financial Leverage Berpengaruh Signifikan terhadap Harga Saham Syariah.

Pengujian Hipotesis ke dua menggunakan uji Interaksi Moderating Regression Analysis (MRA), dimana pada persamaan ini menyertakan variable pemoderasi yaitu Inflasi berupa efek moderasi hasil perkalian variable Financial Leverage dengan Inflasi.

Tabel 1.6

Hasil uji Moderating Regression Analysis

\begin{tabular}{|c|c|c|c|c|c|}
\hline \multirow{2}{*}{\multicolumn{2}{|c|}{ Model }} & \multicolumn{2}{|c|}{$\begin{array}{c}\text { Unstandardized } \\
\text { Coefficients }\end{array}$} & \multirow[t]{2}{*}{$\mathbf{t}$} & \multirow[t]{2}{*}{ Sig. } \\
\hline & & $\bar{B}$ & Std. Error & & \\
\hline \multirow[t]{4}{*}{1} & (Constant) & -17891.256 & 10165.878 & -1.760 & .084 \\
\hline & $X$ & 39327.794 & 9919.923 & 3.965 & .000 \\
\hline & M & 5473.881 & 3236.783 & 1.691 & .096 \\
\hline & $\mathbf{X M}$ & -8877.242 & 3158.493 & -2.811 & .007 \\
\hline
\end{tabular}

Berdasarkan Tabel 1.6 dapat dibentuk persamaan model kedua yaitu persamaan Moderating Regression Analysis (MRA) sebagai berikut :

$$
\mathrm{Y}=-17891.26+39327.79 \mathrm{X}+5473.88 \mathrm{M}-8877.24 \mathrm{XM}
$$

Interpretasi Persamaan MRA adalah :

1. Harga Saham akan turun sebesar 17891.26 jika Financial Leverage, Inflasi dan variable Moderate bernilai Konstan.

2. Jika Financial Leverage naik satu satuan sedangkan Inflasi dan variable moderat bernilai konstan, maka harga saham akan naik sebesar 39327.79

3. Jika Inflasi naik satu satuan sementara Financial Leverage dan Variabel Moderat bernilai konstan, maka Harga Saham Syariah akan naik sebesar 5473.88

4. Jika Variabel Moderat naik satu satuan sementara Financial Leverage dan Inflasi bernilai Konstan, maka Harga Saham akan turun sebesar 8877.24 
Sedangkan untuk uji hipotesis kedua yaitu Inflasi Memoderasi Pengaruh Financial Leverage terhadap Harga Saham Syariah dapat dilihat dari nilai signifikansi variable interaksi XM pada table 1.6, dimana nilai signifikansi variable moderat $(\mathrm{XM})$ sebesar $0.007<0.05$. Karena signifikasi XM $<0.05$ maka dapat disimpulkan Inflasi memodasi pengaruh Financial Leverage terhadap Harga Saham Syariah.

\section{Pembahasan}

Sebagaimana hasil regresi persamaan pertama dimana $\mathrm{Y}=-1147.91+11935.89 \mathrm{X}$ dengan hasil uji signifikasni sebesar $0.000<0.05$ yang berarti ketika Financial Leverage naik satu satuan maka akan meningkatkan Harga Saham Syariah pada perusahaan yang terdaftar pada Jakarta Islamic Index (JII). Penggunaan financial leverage yang besar akan membawa dampak positif bila pendapatan yang diterima dari penggunaan dana tersebut lebih besar daripada beban tetapnya. Oleh karena hal tersebut, investor tidak melihat dampak buruk pada peningkatan Leverage pada perusahaan dengan Saham Syariah, sepanjang perusahaan mampu meningkatkan margin usahanya dibanding dengan beban tetap atas hutangnya.

Hasil penelitian penulis didukung oleh penelitian (Akbar \& Afiezan, 2018) yang juga dilakukan pada saham syariah yang terdaftar di Jakarta Islamic Index dengan variabel Debt To Equity Ratio yang merupakan rasio Financial Leverage. Hasil penelitiannya menunjukkan bahwa Debt To Equity Ratio berpengaruh signifikan terhadap harga saham syariah.

Untuk variable Inflasi yang ditempatkan sebagai variable moderat, pada penelitian ini dapat disimpulkan bahwa Inflasi merupakan variable modetar, hal ini terlihat nilai signifikansi dari variable interaksi XM pada table 1.6 sebesar $0.007<0.05$. sedangkan uji rekresi dengan menggunakan metode uji interaksi diperoleh persamaan regresi $\mathrm{Y}=-17891.26+39327.79 \mathrm{X}$ $+5473.88 \mathrm{M}$ - 8877.24XM yang berarti bahwa jika inflasi meningkat maka harga saham akan turun sebesar 8877.24. Sebagai instrument investasi, saham diharapkan menjanjikan pengembalian yang tinggi meskipun memiliki risiko tinggi pula.

Inflasi merupakan faktor yang tidak dapat diduga, sehingga memiliki potensi dampak negative terhadap iklim investasi. Bagi perusahaan kenaikan inflasi bisa berakibat buruk jika perusahaan tidak mampu menyesuaikan biaya produksi dan menaikan harga barang atau jasa yang diproduksinya. Namun jika Inflasi terlalu tinggi, maka dampak akan berlanjut terhadap daya beli masyarakat, sehingga permintaan akan barang atau jasa akan berkurang. Permintaan yang berkurang akan memaksa perusahaan untuk mengurangi volume produksinya yang lebih jauh akan menurunkan pendapatan perusahaan. Jika Inflasi terus meningkat, maka akan semakin minimal pengembalian atas investasi dan mendorong valuasi pasar semakin rendah. Pada kondisi inilah harga saham akan jatuh pada titik yang mendasar untuk mengimbangi inflasi yang terjadi.

\section{Kesimpulan}

Berdasarkan hasil penelitian dan pembahasan, Financial Lebverage berpengaruh signifikan terhadap Harga Saham Syariah pada perusahaan yang terdaftar di Jakarta Islamic Index (JII), dimana pada persamaan regresi Kenaikan Financial Leverage dapat meningkatkan 
Harga Saham Syariah, hal ini berarti bahwa pasar merespon baik upaya perusahaan dalam membiayai operasional perusahaan untuk dapat meningkatkan laba sepanjang mampu menghasilkan pengembalian yang memadai.

Inflasi merupakan faktor yang tidak dapat diprediksi atau diluar control perusahaan sehingga inflasi berpengaruh negative terhadap harga saham syariah, yang artinya bahwa sebagai variable moderating inflasi mempengaruhi pengaruh Financial Leverage terhadap harga saham syariah pada perusahaan yang terdaftar pada Jakarta Islamic Index (JII).

Inflasi dari tahun ke tahun yang tidak dapat diprediksikan secara pasti, maka baik perusahaan maupun investor diharapkan mampu memanfaatkan waktu siklus ekonomi untuk mengukur pengaruh atau dampak inflasi pada pengembalian saham atau investasinya, sehingga inflasi yang tidak terduga tersebut dapat mengandung informasi baru mengenai harga saham di masa depan.

Berdasarkan hasil penelitian tersebut, saran untuk penelitian selanjutnya diharapkan dapat menggunakan atau menambahkan variable nilai tukar sebagai variable moderating kedua yang dapat mempengaruhi pengaruh Fiannacial Leverage terhadap Harga Saham Syariah pada Jakarta Islamic Index .

\section{Bibliografi}

Agus Sartono. (2012). "Manajemen Keuangan Teori dan Aplikasi" (Edisi4 ed.). BPFE. Yogyakarta.

Akbar, T., \& Afiezan, A. (2018). Determinasi Harga Saham Syariah Melalui Analisis Terhadap 
Faktor Fundamental dan Makro Ekonomi. Jurnal Ilmiah Wahana Akuntansi, 13(1), 1-12. Al Arif, M. N. R. (2012). Lembaga Keuangan Syariah: Suatu Kajian Teoretis Praktis. Pustaka Setia.

Ghozali, I. (2011). Aplikasi analisis multivariate dengan program IBM. Spss.

Ghozali, I. (2016). Aplikasi Analisis Multivariete Dengan Program IBM SPSS 23 (Edisi 8). (Cetakan ke). Badan Penerbit Universitas Diponegoro.

Kamaludin dan Indriani. (2012). Manajemen Keuangan (Edisi Revi). CV. Mandar Maju.

Maisaroh, M., \& Yando, A. D. (2020). Pengaruh Likuiditas, Profitabilitas dan Leverage Terhadap Harga Saham Pada Perusahaan Yang Terdaftar di Bursa Efek Indonesia. SCIENTIA JOURNAL: Jurnal Ilmiah Mahasiswa, 2(1).

Purnomo, S. D., \& Hariyani, I. (2013). Pasar uang dan pasar valas. Jakarta: PT Gramedia Utama.

Racmat dan Mella Putri. (2017). "Pengaruh Finanacial Leverage dan Profitabilitas Terhadap Harga Saham Studi pada Perusahaan Sub Sektor Perkebunan yang terdaftar di Bursa Efek Indonesia Tahun 2011-2015”.

Sugiyono. (2014). Metode Penelitian Kuantitatif, Kualitatif dan $R \&$ D. Alfabeta. 